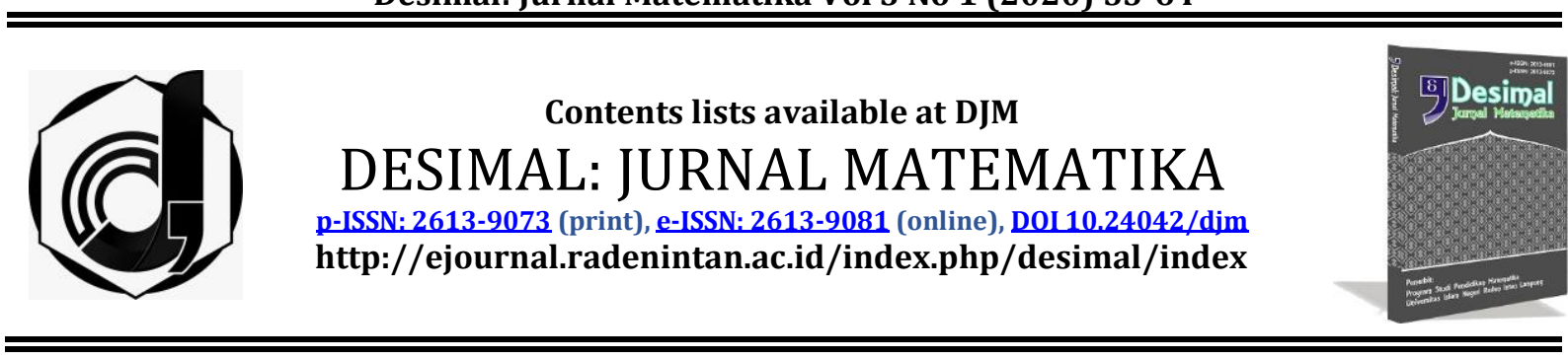

\title{
Student Procedural Fluency in Numerical Method Subjects
}

\author{
Sarah Inayah*, Ari Septian, Ramdhan Fazrianto S. \\ ${ }^{1}$ Universitas Suryakancana, Indonesia
}

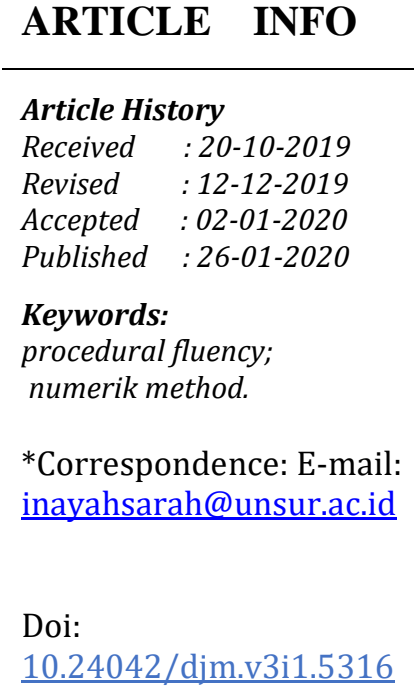

\begin{abstract}
This study aims to explain the procedural fluency of students in numerical methods courses. Procedural fluency refers to knowledge of procedures, about when and how to use them appropriately, and the skills to carry out procedures flexibly, accurately, and efficiently. The method in this study uses a descriptive method with a qualitative approach and data analysis techniques for the Miles and Huberman models. In this study also performed triangulation of techniques by conducting interviews to strengthen the test result data. From the data analysis, it can be concluded that regarding the smoothness in students' procedural procedures in solving problems related to numerical methods courses, students are able to solve problems with more than one method. However, some students have not been able to streamline steps and make accurate calculations. In addition, mastery in operating a scientific calculator needs to be improved so that students can be more efficient and get more accurate answers.
\end{abstract}

\section{INTRODUCTION}

Education is very closely related to learning. Learning has goals that lead to the development of superior and highquality human potential. The success of a learning process is greatly influenced by the teacher's role in planning, implementing, and evaluating the learning process and outcomes.

Being a teacher is a choice that must be accounted for. A teacher is said to be qualified if he can meet four competency standards consisting of pedagogical, personal, social and professional competencies (Ministry of National Education, 2005). The four competencies are none whose position is more important than the others. All are equally important to be owned by a teacher. Teacher Training Institute (LPTK) has a role in preparing teacher candidates to fulfill the four competencies.

One of the core competencies in teacher professional competency standards is to master the material, structure, concepts, and scientific mindset that supports the subjects being taught. One of the benchmarks of how the professional competence of teachers in 
Desimal, 3 (1), 2020 - 54

Sarah Inayah, Ari Septian, Ramdhan Fazrianto S.

Indonesia is through the Teacher Competency Test (UKG). UKG is a test of the ability of teachers implemented by the government. The material tested in the UKG covers 30 percent of pedagogical competencies and 70 percent of professional competencies (Ministry of Education and Culture, 2016).

The UKG results are a special note for LPTK which has a role in preparing prospective teachers to become competent teachers. The competencies that are directly taught and trained through lectures are professional competencies. A mathematics teacher is said to have professional competence if he masters the material, structure, concepts, and scientific mindset that supports mathematics. So before being able to teach mathematics, the teacher must be proficient in mathematics. In other words it is very important that a prospective mathematics teacher student has mathematical skills.

Mathematics is one of the disciplines studied and taught at every level of education ranging from elementary school to college (Anggriani \& Septian, 2019). Mathematics is a structured science and in it there is an algorithm as a general procedure. When students have gained knowledge about general procedures in mathematics, it means students have gained procedural fluency skills. The ability of procedural fluency is needed to support other aspects of mathematical skills.

Mathematical procedural fluency is related to students' understanding of a mathematical concept and solving mathematical problems. Through the smoothness of mathematical procedures students can know the level of understanding of a mathematical concept. Besides that through mathematical procedural fluency students can solve mathematical problems well. This ability is an important ability mastered by students. However, the results of
Aprianti's (2014) research on the smoothness of students' mathematical procedures in calculating operation material in fractions in junior high school concluded that none of the students or $0 \%$ had a smooth mathematical procedure included in the current category. In addition, from the results of Asmida's (2016) research on conceptual understanding and procedural fluency of students in integer count operations material, it was found that students' procedural fluency was in the medium category with a percentage of $68 \%$.

Given the importance of mathematical procedural fluency for students, while there are still problems in these abilities, prospective mathematics teacher students must master it well as a provision to guide students. Based on the research results of Astuty (2015) shows that teacher competence has a positive and significant effect on student achievement.

Learning numerical methods focuses on procedural fluency. The numerical method is a systematic way to solve mathematical problems by operating numbers (add, subtract, multiply, divide). There are several reasons why learning numerical methods, one of them numerical methods is a tool to solve mathematical problems that are very reliable. Many technical problems that are impossible can be solved analytically, can be solved by numerical methods. Therefore, previous research has tested in order to improve learning outcomes with a variety of methods and developments such as using Problem Solving-based discovery learning models and problem solving-based group investigations that have greater results on using the group investigation model (Vahlia \& Agustina, 2016), Other researchers have also tested the improvement of learning outcomes in numerical subjects using cooperative jigsaw which resulted in an increase of $23.33 \%$ which has an influence on 
Desimal, 3 (1), 2020 - 55

Sarah Inayah, Ari Septian, Ramdhan Fazrianto S.

improving learning outcomes (Shoffa \& Suprapti, 2017). Other researchers have used numerical methods to examine the symbolizations contained therein as well as representations of concepts and procedures (Mulyatna \& Kusumaningtyas, 2017), other researchers developed a constructivist-based numerical method textbook (Khaidir, 2016), other researchers developed instructional materials also for numerical methods based on problem solving (Fadillah, nd), other researchers in conducting research by using student worksheets as learning media for numerical methods courses (Purwati, 2016), other researchers tested numerical methods for the effectiveness of the Ideal Problem Solving learning model (Purnomo, Prasetyo, \& Budiharto, 2016), other researchers tested the improvement of student skills Through guided inquiry practicum activities (Rakhmawati \& Hartiningrum, 2019), other researchers developed the adaptive learning system using SAW to determine the value of learning (Putra, Wirawan, \& Sugihartini, 2018), and other researchers also implemented strategies for applying the JIGSAW learning model (Nawafilah \& Masruroh, 2018) from several previous studies, many researchers tested the improvement of learning outcomes on numerical methods. Therefore, the researchers are currently testing how the students' procedural fluency in numerical methods courses.

In the procedural fluency, many researchers used to test various aspects. This includes research conducted by Fatimatul Khikmiyah and Irwani Zawawi in 2013 entitled Analysis of Student Mathematical Skills in Statistics-1 Subjects with Problem-Based Collaborative Learning. The results in the study showed that the students' mathematical abilities had increased in each cycle and were in the good category even very well in procedural fluency (Khikmiyah, F and Zawawi, I, 2013).
Another study was conducted by Asmida in 2016 entitled Conceptual Understanding and Procedural Smoothness of Students in Round Number Operations in Junior High School. The results of this study indicate that conceptual understanding and procedural fluency are in the medium category with percentages of $70 \%$ and $68 \%$, respectively. In the procedural fluency it appears that the lowest flexibility indicator is then accurate and efficient. (Asmida, 2016). Another study entitled Mathematical etudes: embedding opportunities for developing procedural fluency within rich mathematical contexts (Foster, 2013), procedural fluency was also tested on PTLSV material in terms of the learning style of Islamic boarding school students (Hartoyo \& Suratman, 2018). Other researchers also tested procedural fluency in learning ALJABAR MATRIKS through the use of MAPLE (Setyansah \& Masfingatin, 2017), other researchers tested by developing Scrabble media to improve procedural fluency (Kusumaningtyas \& Yunianta, 2019), other researchers also analyzed procedural fluency in the material equation equation exponential (Haryandika, Utami, \& Prihatiningtyas, 2017), other researchers also tested procedural fluency in Integer Operations (Valmoria \& Tan, 2019), other researchers tested mathematical procedural fluency in solving marketing context problems (Fatimah \& Zakiah, 2018), researchers others test procedural fluency in AIDS learning (Asmida, Sugiatno, \& Hartoyo, 2018)

Departing from this phenomenon, the researcher is interested in taking up this theme with the aim of analyzing and describing the mathematical procedural fluency of students when solving problems in numerical methods courses.

\section{METHOD}


Desimal, 3 (1), 2020 - 56

Sarah Inayah, Ari Septian, Ramdhan Fazrianto S.

The research used to explain students' mathematical procedures in numerical methods courses is a descriptive research method. The form of research used in this study is survey research. Survey research is a question of facts, facts, facts, facts, facts, facts, facts, facts, facts, facts, facts, facts, facts and facts (Creswell, 2007).

This research was conducted at the Mathematics Education Study Program FKIP Suryakancana University. The subjects in this study were students of semester VI in the academic year 2017/2018. The sixth semester students of the Mathematics Education Study Program FKIP Suryakancana University class A in the academic year 2017/2018 were debated by 26 people, consisting of 22 female students and 4 male students. The object of this research is the mathematical procedures of students in numerical methods courses.

\section{Research Instruments}

The instruments in this study consisted of documentation and interviews.

1. Documentation

a. Syllabus of courses

The syllabus is a reference for the preparation of the learning framework for each subject matter study. The syllabus is also used as a reference in developing semester learning plans.

b. Semester Learning Plan (RPS)

RPS is a learning planning document that is prepared as a guide for students in carrying out lecture activities for one semester to achieve predetermined learning outcomes.

c. Test kit

The test used to measure the mathematical procedural fluency of students in numerical methods courses. The test were in the form of a written test essay amounting to 3 questions that include 3 indicators of mathematical procedural fluency.

The instrument test is tested for validity and reliability first. Based on the calculation of the question test, it was found that the three questions were valid and reliable so that it was feasible to be used as an instrument in this study. The results of the validity and reliability can be seen in Table 1 .

Table 1 Calculation of Test Trial

\begin{tabular}{cc}
\hline $\begin{array}{c}\text { Validity and } \\
\text { classification }\end{array}$ & $\begin{array}{c}\text { Reliability and } \\
\text { classification }\end{array}$ \\
0,816 & \\
(very significant) & 0,72 (high) \\
0,650 (significant) & \\
0,621 (significant) & \\
\hline
\end{tabular}

2. Interview

Besides, interview is another instrument used in this study. The interviews used to obtain information about the broad outlines of solving mathematical procedural test questions.

\section{Data Collection Technique}

The data collection technique used is triangulation technique. Triangulation is a data collection technique from various sources. (Sugiyono, 2013). Data collection techniques used are documentation and interviews. Documentation in the form of written test results (essays) from students. The essay test requires test participants to provide answers in their own compiled descriptions or sentences.

The procedure of compiling the test includes making the item grid, writing the item, testing to measure the validity and reliability of the questions. Next to strengthen the data, interviews were conducted. The research design can be seen in Figure 1. 
Desimal, 3 (1), 2020 - 57

Sarah Inayah, Ari Septian, Ramdhan Fazrianto S.

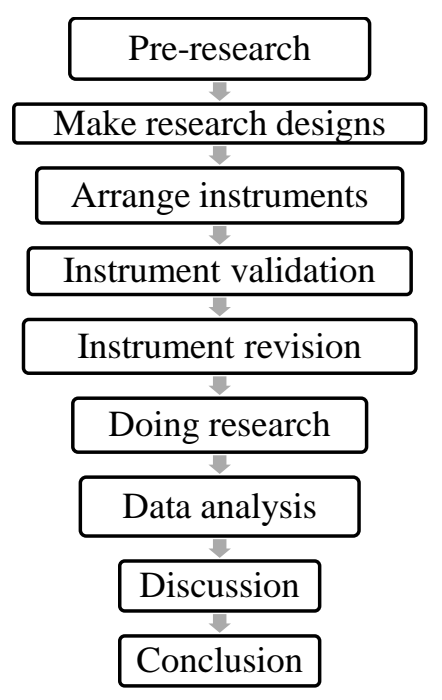

Figure 1. Research Design

\section{Data Analysis Technique}

This study uses a qualitative approach with the analysis technique of the Miles and Huberman model (Sugiyono, 2013). The steps of analyzing the Miles and Huberman data model are data reduction, data presentation, drawing conclusions, and verification. In the reduction stage, the achievement of students' mathematical procedural fluency through mathematical problem solving is examined according to the selected indicators. Then in the data presentation stage, each indicator of mathematical procedural fluency conducted by students when solving mathematical problems is presented. In the final stage that is drawing conclusions and verifying the results of the analysis descriptively.

\section{RESULTS AND DISCUSSION}

Based on data analysis, it is known that the level of mathematical procedural fluency of FKIP UNSUR mathematics education students has an average percentage of $63.33 \%$. This percentage is in the moderate category. The lowest value is 36.67 and the highest is 90 . Data can be seen in Table 2 .
Table 2. Student Procedural Smoothness Test Results (Achievement in percent)

\begin{tabular}{|c|c|c|c|}
\hline Aspect & $\begin{array}{l}\text { Minimum } \\
\text { score }\end{array}$ & $\begin{array}{c}\text { Maximum } \\
\text { score }\end{array}$ & Average \\
\hline & 25 & 100 & 83,27 \\
\hline & 1 & 90 & 4 \\
\hline Efficien & 25 & 100 & 69,23 \\
\hline
\end{tabular}

Based on Table 2, the highest flexible indicator with a percentage of $83.27 \%$ is included in the high category. The lowest value on this indicator is $25 \%$ and the highest is $100 \%$. Of the 26 students, the classification details on the flexible indicator are 22 students in the high category, 3 people in the medium category and 1 person in the low category.

While the level of mathematical procedural fluency of FKIP UNSUR Mathematics Education students on accurate indicators has an average of $61.54 \%$ including the medium category. The highest percentage is $90 \%$ with a high category. The lowest level of procedural mathematical accuracy with a percentage of $15 \%$ with a low category. Of the 26 students, the classification details on the flexible indicator are 10 students in the high category, 14 people in the medium category and 2 people in the low category.

The level of mathematical procedural fluency of FKIP UNSUR Mathematics Education students on efficient indicators has an average of $69.23 \%$ including the medium category. The lowest value on this indicator is $25 \%$ and the highest is $100 \%$. Of the 26 students, the breakdown of classification on flexible indicators is 13 students in the high category, 12 people in the medium category and 1 person in the low category.

The students' mathematical procedural fluency has not been maximized, it is suspected that while learning takes place, the smoothness of the procedure exercises has not been maximally provided. The existence of students who are low in the mathematical procedural fluency is a problem and must be taken by an educator, this is to improve 
Desimal, 3 (1), 2020 - 58

Sarah Inayah, Ari Septian, Ramdhan Fazrianto S.

learning achievement and student learning outcomes.

After knowing the test results, the next step is to choose 4 students who have a match between the test results and the interview. The selected students are A1, A14, A15 and A18 and the following results of the analysis of the student's procedural fluency.

1. A1 Student

A1 Students know the method of solving with various methods, A1 also knows the procedures that must be carried out, but at the time of the test, A1 students only complete with one method. A1 explained that he took too long to settle with one method so that he could not continue with the second method. In answering other questions, A1 students made a mistake and were less efficient. Student A1 explained that he was only slightly inaccurate and had technical problems in applying scientific calculators. So after giving the test and interviewing A1 students based on procedural fluency indicators used by researchers in this study that A1 students meet flexibility but do not meet the accuracy and efficiency indicators.

2. A14 Student

A14 Students know the method of completing in more than one way, A14 also knows the procedures that must be carried out, but in one of the methods has not been completed and has not reached the final results. A14 explains that it takes too long to solve with one method so that the time given to answer questions with the second method is not enough. In answering other questions, A14 students made mistakes and were less efficient. Student A14 explained that he forgot the initial procedures and was not thorough and had technical problems in applying scientific calculators. So that after the test was given and conducted interviews with A14 students based on procedural fluency indicators used by researchers in this study that A14 students met flexibility but did not meet the accuracy and efficiency indicators.

3. A15 student

A15 student only knows one method in solving the first problem, A15 is also not complete in solving the method that he knows in the first problem. A15 explains that he does not yet understand the problem he is having. In answering the second problem, A15 students did not make mistakes in applying the procedure. But the third problem seems less efficient in implementing procedures. A15 student explained that he was just a little lacking in self-confidence so that there were doubts. So after the test was given and conducted interviews with A15 students based on procedural fluency indicators used by researchers in this study that A15 Students met accuracy but did not meet the indicators of flexibility and efficiency.

4. A18 students

A18 students know the method of completing in more than one way, A18 also knows the procedures that must be carried out, but in one of the methods has not been completed and has not reached the final results. A18 explains that it takes too long to solve one method so that the time given for answering questions with the second method is not enough. In answering other questions, A18 students made a mistake and were less efficient. A18 student explained that he was only a little bit less thorough and had technical problems in applying scientific calculators. So after the test was given and conducted interviews with A18 students based on procedural fluency indicators used by researchers in this study that A18 students met flexibility but did not 
Desimal, 3 (1), 2020 - 59

Sarah Inayah, Ari Septian, Ramdhan Fazrianto S.

meet the accuracy and efficiency indicators.

Based on the research that has been done, it can be seen that the procedural fluency of students in numerical methods courses is in the medium category, can be detailed as follows.

\section{Flexibelity}

In this study aspects of student flexibility can be seen from the way students determine methods for solving problems and carry out problem solving procedures using methods that they know can be used. It also means that students must be able to use more than one way to solve problems. Almost all students have been able to do that. For a given problem, students can choose to use the closed method (bagidua or rulefalsi) to find a solution of a non-linear equation at a certain interval. After the interview, it turns out that most of them prioritize using the regula-falsi method because in general it is faster in finding solutions. Even in daily practice when given the freedom to choose a method, students more often use the method of regulation-function. Therefore there is a sense of reluctance to use a method for two that will take more steps to arrive at a solution. But only a small percentage felt that way. When compared with other aspects, flexibility is the highest aspect achieved by students. This is very contrary to the results of research by Asmida (2016) who actually found this aspect the lowest achieved. This happens because of differences in age levels on research subjects that also affect their mindset. Middle school students are in the youth category and students in the adult category. Adults have more flexibility in their mindsets, can understand that there are diverse opinions in one problem and there is more than one way that can be used to approach a problem.

\section{Accuration}

This indicator is the most difficult indicator for students to achieve. This can be seen from the lowest achievement compared to the other two indicators. Not a few students make mistakes, especially in arithmetic operations, which occur because of a lack of accuracy in rechecking the results they get. The results obtained in the initial step are very influential in the next step. So that errors in rounding in the initial steps will affect accuracy in the later stages. Besides that technically, mastery in the use of scientific calculators is needed.

The test used to measure the level of accuracy of students is through problems that require students to estimate the value of a particular point function with a Newton degree polynomial. Problems like this require students to do several stages / procedures to form Newton's polynomial, which consists of polynomials having degrees one, two and then three, only then can substitute points. In determining the polynomials, the constants must first be determined by the procedure for determining the value of divideddiffrence. All of these stages are related to one another, so high accuracy is needed at each step.

For the aspect of accuracy, most students are able to translate the intent of the problem given. But there are still students who still make mistakes both in calculation and the steps missed so as to produce an incorrect answer, and none of the students reaches a perfect score until the final answer to the problem given.

\section{Efficiency}

Based on the results of student answers, some students have not been able to solve mathematical problems 
with the completion or procedure with the shortest possible time and correct, in other words on the aspect of the average efficiency of student answers included in the medium category. There are some students who get a short answer but the method chosen is not the one asked for in the problem. So it can be said that the procedure chosen was not right. A common mistake that occurs is to continue until the seventh and even ten iterations, even though the fifth iteration already seems to lead to a solution. After tracing the cause of this through interviews, it was found that they felt less confident with the answers they found, so proceeding was not really necessary.

If seen from all aspects obtained that the procedural fluency of students is in the medium category that is $71 \%$. This is different from the findings of Khikmiyah, F and Zawawi, I (2013) which states that the procedural fluency of students is in the very good category. This could happen because of differences in subjects namely the numerical method in this study which was considered new and difficult by students while the statistics- 1 they had learned the basics when in high school. In addition, differences in the use of learning models, namely problembased collaborative learning, can be used as a reference in order to maximize the achievement of students' procedural fluency.

Because the students 'mathematical procedural fluency is not yet maximal, theories of learning are needed in an effort to improve students' mathematical procedural fluency. Learning theories that support procedural fluency include Bruner's learning theory and Gagne's learning theory. Bruner's learning theory focuses its attention on the problem of what humans do with the information they receive and what they do after obtaining that discrete information to reach an understanding that gives them abilities. According to Bruner the core of learning is about how people choose, pay attention and actively transform information. Bruner suggested four themes about education namely; (1) the importance of knowledge structures; (2) readiness to learn; (3) the value of intuition in the education process; (4) motivation for (Sutawidjaja \& Afgani, 2015). Knowledge structure helps students to see how facts that are not related can be related to one another. Learning readiness is related to the mastery of simpler skills that can allow a person to attain higher skills. The value of intuition in the educational process means that with intuitive intellectual techniques to arrive at tentative formulations without going through analytical steps to find out the formulation is the correct conclusion or not. The final theme is motivation or the desire to learn and ways teachers have to grow that motivation.

Meanwhile, according to Gagne's learning theory there are eight phases in an action learning. The eight phases in question are 1) The motivational phase; 2) Introduction phase; 3) The acquisition phase; 4) Retention phase; 5) Calling phase; 6) Generalization phase; 7) Appearance phase; and 8) Feedback phase (Sutawidjaja \& Afgani, 2015). Students who learn must be motivated to learn with hope. By expressing the usefulness of the learning to be implemented can foster motivation in students. In the introduction phase students must pay attention to the essential parts of an instructional study. When students pay attention to relevant information, they are ready to receive lessons. Information is not directly absorbed in memory when it is presented, the 
information is converted into a meaningful form that is linked to the material that is already in student memory. The retention phase is the phase of transferring information from short term memory to long term memory. This can happen through rehearsal, practice, elaboration and others. Maybe we can lose touch with information from long-term memory. So an important part of learning is to obtain relationships from what has been learned, to call information that has been learned before. In the generalization phase is the phase of information transfer, which uses information in new circumstances. Learning outcomes need to be demonstrated in a way, so that the teacher and students themselves know whether the learning objectives have been achieved. The teacher should provide opportunities for students to show their learning outcomes so they can be given feedback. Ways that can be done through testing or observing student behavior.

The two learning theories are in line with the opinions formulated by the National Council of Teachers of Mathematics / NCTM (2014), which is to develop procedural fluency, students need experience in linking concepts and procedures, as well as building familiar procedures, because they create informal strategies and procedures themselves. Students need the opportunity to justify informal strategies and procedures commonly used mathematically, to support and justify their choices regarding appropriate procedures, and to strengthen their understanding and skills through distribution practice.

With the theory of learning Bruner and Gagne and the opinion of NCTM, it is hoped that it can improve students' mathematical posedural fluency in FKIP UNSUR mathematics education students, so students can improve their achievements and support the achievement of other mathematical skills. This is the same as previous researchers which require reinforcement of procedural fluency (Valmoria \& Tan, 2019), and also this is the same as researchers before where researchers concluded that students were instructed to be more careful again (Haryandika et al., 2017).

\section{CONCLUSIONS AND SUGGESTIONS}

Based on the analysis and discussions, it can be concluded that the procedural fluency of FKIP UNSUR Mathematics Education students in solving questions related to numerical methods courses can be seen that almost all students have been able to solve problems in more than one way or method. Some students have not been able to streamline steps and have not been able to do accurate calculations. In addition, mastery in operating a scientific calculator needs to be improved which will help students work more efficiently and get more accurate answers.

Based on the findings in this study it is expected that other researchers are expected to conduct further research with other research methods to explore the abilities of students and students aimed at improving and enhancing the ability of students and students to run procedural smoothly.

\section{REFERENCE}

Anggriani, A., \& Septian, A. (2019). Peningkatan Kemampuan Komunikasi Matematis dan Kebiasaan Berpikir Siswa Melalui Model Pembelajaran IMPROVE. IndoMath: Indonesia Mathematics Education, 2(2), 105-116. https://doi.org/10.30738/indomath. v2i2.4550

Asmida, A., Sugiatno, S., \& Hartoyo, A. 
Desimal, 3 (1), 2020 - 62

Sarah Inayah, Ari Septian, Ramdhan Fazrianto S.

(2018). Developing The Mathematics Conceptual Understanding And Procedural Fluency Through Didactical Anticipatory Approach Equipped With Teaching Aids. Journal of Education, Teaching and Learning, $3(2), 367-372$.

Creswell, J. W. (2007). Research Design: Qualitative, Quantitative and Mixed Method Aproaches. SAGE Publications, 203-223. https://doi.org/10.4135/97818492 08956

Depdiknas. (2005). Undang-undang Republik Indonesia Nomor 14 Tahun 2005 tentang Guru dan Dosen. Produk Hukum, 54.

Fadillah, A. (n.d.). Pengembangan Bahan Ajar Metode Numerik Dengan. Pedagogy: Journal Pendidikan Matematika, 2(1), 12-19.

Fatimah, A. T., \& Zakiah, N. E. (2018). Kelancaran Prosedural Matematis Dalam Pemecahan Masalah Konteks Pemasaran. Jurnal Matematika Dan Pendidikan Matematika, 3(2), 141150.

Foster, C. (2013). Mathematical études: embedding opportunities for developing procedural fluency within rich mathematical contexts. International Journal of Mathematical Education in Science and Technology, 44(5), 765-774. https://doi.org/10.1080/0020739X. 2013.770089

Hartoyo, A., \& Suratman, D. (2018). Deskripsi Pemahaman Konseptual Dan Kelancaran Prosedural Materi Ptlsv Ditinjau Dari Gaya Belajar Siswa Pondok Pesantren.

Haryandika, U. W., Utami, C., \& Prihatiningtyas, N. C. (2017). Analisis Kelancaran Prosedural Matematis Siswa Pada Materi Persamaan Eksponen Kelas X Sma Negeri 2 Singkawang. Jurnal Pendidikan Matematika Indonesia, 2(2), 72-77. kemendikbud. (2016).

GURU
PEMBELAJAR Pedoman Program Peningkatan Kompetensi. In GURU PEMBELAJAR Pedoman Program Peningkatan Kompetensi (p. 52).

Khaidir, C. (2016). Pengembangan Buku Ajar Metode Numerik Berbasis Konstruktivisme Di Iain Batusangkar. Ta'dib, 19(1), 67. https://doi.org/10.31958/jt.v19i1.4 52

Kusumaningtyas, I., \& Yunianta, T. N. H. (2019). Pengembangan Media Scrabble untuk Meningkatkan Procedural Fluency Matematika Siswa SMP. Journal Cendekia: Jurnal Pendidikan Matematika, 03(02), 300314.

Mulyatna, F., \& Kusumaningtyas, W. (2017). Simbolisasi dalam Metode Numerik sebagai Representasi Konsep dan Prosedur. NUMERICAL: Jurnal Matematika Dan Pendidikan Matematika, 1(2), 73-86. https://doi.org/10.25217/numerical .v1i2.129

Nawafilah, N. Q., \& Masruroh, M. (2018). Strategi Penerapan Model Pembelajaran Kooperatif Tipe Jigsaw Pada Mata Kuliah Metode Numerik. Jurnal Mathematic Paedagogic, 2(2), 157-165. https://doi.org/10.36294/jmp.v2i2. 214

Purnomo, eko andy, Prasetyo, M. T., \& Budiharto, B. (2016). Keefektifan Model Pembelajaran Ideal Problem Solving Berbasis Maple Matakuliah Metode Numerik. Jurnal.Unimus.Ac.Id, $3(2), 45-52$.

Purwati, ni kadek rini. (2016). Penggunaan Lembar Kerja Mahasiswa Sebagai Media Pembelajaran Mata Kuliah Metode Numerik . Emansains : Jurnal Edukasi Matematika Dan Sains, 5(2), 8-13. https://doi.org/10.1017/CB097811 07415324.004

Putra, I. M. G., Wirawan, I. M. A., \& Sugihartini,

N.

(2018). 
Desimal, 3 (1), 2020 - 63

Sarah Inayah, Ari Septian, Ramdhan Fazrianto S.

Pengembangan Sistem Adaptive Learning Menggunakan Metode Saw(Simple Additive Weighting) Untuk Menentukan Nilai Pembelajaran Pada Mata Kuliah Metode Numerik. Jurnal Nasional Pendidikan Teknik Informatika (JANAPATI), 7(3), 271-283. https://doi.org/10.23887/janapati.v 7i3.13438

Rakhmawati, N., \& Hartiningrum, E. S. N. (2019). Peningkatan Ketrampilan Mahasiswa Melalui Kegiatan Praktikum Inkuiri Terbimbing pada Mata Kuliah Metode Numerik. Jurnal Ilmiah Soulmath: Jurnal Edukasi Pendidikan Matematika, 7(2), 125134.

https://doi.org/10.25139/smj.v7i2.1 974

Setyansah, R. K., \& Masfingatin, T. (2017). Procedural Fluency Mahasiswa Berkemampuan Tinggi Pada Pembelajaran Aljabar Matriks Melalui Penggunaan Maple. Jurnal Penelitian LPPM IKIP PGRI Madiun, 5(1), 29-36.

Shoffa, S., \& Suprapti, E. (2017). Peningkatan Hasil Belajar Mahasiswa pada Mata Kuliah Metode Numerik dengan Model Pembelajaran Kooperatif Jigsaw. MUST: Journal of Mathematics Education, Science and Technology, 2(2), 178-188. Retrieved from http://journal.umsurabaya.ac.id/index.php/matematik a/article/view/736

Sutawidjaja, A., \& Afgani, J. (2015). Konsep Dasar Pembelajaran Matematika. Pembelajaran Matematika, 1-25.

Vahlia, I., \& Agustina, R. (2016). Perbandingan Hasil Belajar Discovery Learning Berbasis Problem Solving Dan Group Investigation Berbasis Problem Solving Pada Pembelajaran Metode Numerik. AKSIOMA Journal of Mathematics Education, 5(1), 82-93. https://doi.org/10.24127/ajpm.v5i1 .469

Valmoria, E. L. Z., \& Tan, R. G. (2019).
Sequences Of Mathematical Tasks For Intensifying Procedural Fluency In Integer Operation. 31(3), 457-460. 
Desimal, 3 (1), 2020 - 64

Sarah Inayah, Ari Septian, Ramdhan Fazrianto S. 